\title{
AUTOMATION OF DRINKING WATER TREATMENT SYSTEMS IN RURAL AREA
}

\author{
Eko NURSUBIYANTORO' ${ }^{1}$ ISMIANTI ${ }^{1}$, Astrid Wahyu Adventri WIBOWO ${ }^{1}$
}

DOI: $10.21163 / G T \_2020.151 .28$

\begin{abstract}
:
All living things need water to live. The increasing population in the world results the increased demand of water, include in Indonesia. Water scarcity is also a big issue in Indonesia, especially in rural area like Gunung Kidul. In Gunung Kidul people difficult to get clean water. Clean water can be obtained with drinking water system. The drinking water system that now exist in Temuireng Village, Girisuko, Panggang, Gunung Kidul could meet the water need of the people, but there is a problem with the design of the water treatment system. The drinking water treatment system still use semimanual mechanism that less effective and efficient. The purpose of this research is to design the automatic drinking water treatment system that now exist in Temuireng Village to improve the quality of the water in that area and to reduce the operating cost of the systems. With considering the need, technology and some other aspects, this research obtained the new prototype design of the drinking water treatment systems that be equipped with automation.
\end{abstract}

Key-words: Automation, Design, Prototype, Rural area, Water treatment system

\section{INTRODUCTION}

Water is one of the most important resources for life. All living things need water to live and develop. Safe water is important for humans, plants, and animals (Abu Hasan, Muhammad, \& Ismail, 2020). In Indonesia, the increasing population results the increased demand of water but the water resource availability was limited (Kardono, 2007). Many water sources that are commonly used are not as good as they used to be (Wiyono, Faturrahman, \& Syauqiah, 2017). Once the water has been contaminated by toxic compounds, it must be treated before can be consumed by people (Abu Hasan et al., 2020). The water contaminations occur because of a few key factors, i.e. industrial and sewage effluent discharge, agricultural industry, illegal garbage disposal and leakage of leachate from landfills (Hasan, Abdullah, Kofli, \& Yeoh, 2016).

Nowadays, clean water supply becomes one of the big issues in the world, especially in developing country (Nandiyanto \& Haristiani, 2016). Unlike urban areas where water pollution is usually caused by poor wastewater treatment, in rural areas water sources are still good but the problem is the difficulty of accessing good water source (Apip, Sagala, \& Pingping, 2015) (Luo et al., 2019). This scarcity of water can cause the disruption of life. This water scarcity is main issue in Gunung Kidul, includes in Temuireng, Girisuko, Panggang, Gunung Kidul, Yogyakarta (Sugiarto \& Suharwanto, 2017). Water stress can caused by lack of awareness of tree planting, the use of water for households is increasing, exploration and use of water for industrial, especially manufacturing (Dwianika, Murwaningsari, \& Suparta, 2020). (Haryadi \& Sudarmadji, 2014). Gunung Kidul as an area

\footnotetext{
${ }^{1}$ Universitas Pembangunan Nasional Veteran Yogyakarta, Jl. SWK 104 Lingkar Utara, Condong Catur,Yogyakarta,Indonesia,eko_nsby072@upnyk.ac.id; ismianti@upnyk.ac.id; astrid.wahyu@upnyk.ac.id.
} 
with water scarcity and dryness, one of the reasons is because of the morphology of the area (Haryadi \& Sudarmadji, 2014). Gunung Kidul as a mountain area, like in other natural places indicate a low degree of urbanization, but at the same time, these regions are facing global natural changes (Nistor et al., 2018).

The consequence from drought was a lack of consumable water to be used in various activities (Rotjanakusol \& Laosuwan, 2019), especially in agriculture which is the main career of the people in Gunung Kidul. In Gunung Kidul, the ground water conditions is also influenced by climate like the other semi-arid region (Chamchati \& Bahir, 2011). Gunung Kidul area is a karst topography region formed from limestone dissolution. In areas with karst topography, rain water that falls on the surface will immediately soak into the ground and form underground rivers. This makes it difficult to get clean water on the surface, especially in the dry season. However, the availability of ground water is very abundant with good water quality in the area. Technology is needed with the main goal of helping to provide clean water and ensure healthy lives (Kabisch, 2016). Ground water can be raised with appropriate (Sugiarto \& Suharwanto, 2017).

One of the technology that can be used to raise the ground water is water treatment system. Water treatment systems have been researched, developed and used in various regions. This water treatment system can be done by various methods according to the needs and conditions of the water source. One of the water treatment systems is conducted by Wiyono, Faturrahman, and Syauqiah (2017) carried out by aeration, filtration, adsorption, and disinfection. However, in this system the design of tools is less effective because the quality of the water produced does not meet the established quality standards (Sugiarto \& Suharwanto, 2017). The other drinking water systems has been develop by Sugiarto and Suharwanto (2017) in Gunung Kidul. This drinking water treatment system was developed to reduce E-coli bacteria, organic matter (coliform parameters) and inorganic materials (TDS parameters) by the process of deposition, slow sand filter, and splash distortion of solar power (Sugiarto \& Suharwanto, 2017). This treatment system can reduces TDS from $400 \mathrm{ppm}$ to below 160 ppm.

Public service availability and quality remain relatively low in the rural areas, particularly in developing country (Yang, Liu, Phang, \& Wei, 2020), including water treatment systems in Temuireng. In that area, the mechanisme of drinking water treatment systems still uses semi-manual work (Sugiarto \& Suharwanto, 2017). The role of labor was still dominant to running the systems. In recent times, to ensure the continuous supply of good quality and safe of water, the water treatment system is equipped with automation controls (Dubey, Agarwal, Gupta, Dohare, \& Upadhyaya, 2016). The development of drinking water treatment system with integrated automation is expected to help the community in fulfilling water, safer, cheaper and easier. With the automation, the quality of the water from water treatment systems can be improved (Handayani, Kusnayat, Sukma, \& Atmaja, 2017). In addition, water distribution systems can also become more efficient through automation (Gowtham, Varunkumar, \& Tulsiram, 2017).This paper wants to explain the continuation of research from Sugiarto et al. in the form of a prototype design of an automated drinking water treatment system.

\section{METHODOLOGY}

Object of this research is drinking water treatment system that located in Temuireng village, Girisuko, Panggang, Gunung Kidul, Yogyakarta, Indonesia. This drinking water 
treatment was used to fulfill the water demand approximately 269 families in that area. The steps of this research can be seen in Fig. 1.

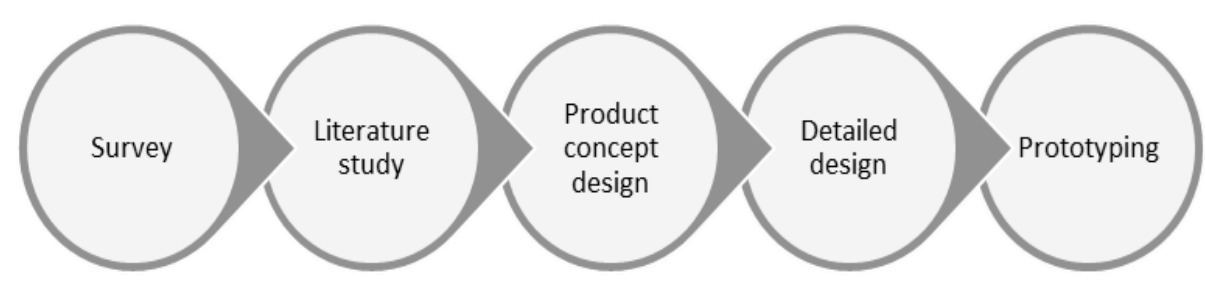

Fig.1. Steps of the research

1. Survey

The first step of this research was survey in the location of the drinking water treatment system in Temuireng village, Girisuko, Panggang, Gunung Kidul. The survey was conducted to determine the needs of the current drinking water treatment system.

2. Literature Study

Literature study is conducted to find out the current drinking water treatment system in other places. This study was also conducted to add information in product design.

3. Product Concept Design

Product concept design is done by considering the needs, technology and SHE IS FATER (Tontowi, 2016). SHE IS FATER is the concept of product design that considering (1) SHE (Safety, Health, Environment), (2) Innovation and intellectual property rights, (3) Standard of the product, (4) Function, (5) Aesthetics, (6) Trends of the product, (7) Ergonomics, (8) Regulation.

4. Detailed Design

After the product concept is obtained, the next is the detailed design of the product.

5. Prototyping

After the detailed design of the product is obtained, the next step is to make a prototype.

Prototype is made on a laboratory scale.

\section{RESULT AND DISCUSSION}

\subsection{Overview of Society and Needs}

Gunung Kidul is known as arid regions and droughts in the dry season. The drinking water treatment system is located in Temuireng village, Girisuko, Panggang, Gunung Kidul. Fig. 2 is map of the location of a drinking water treatment system. 


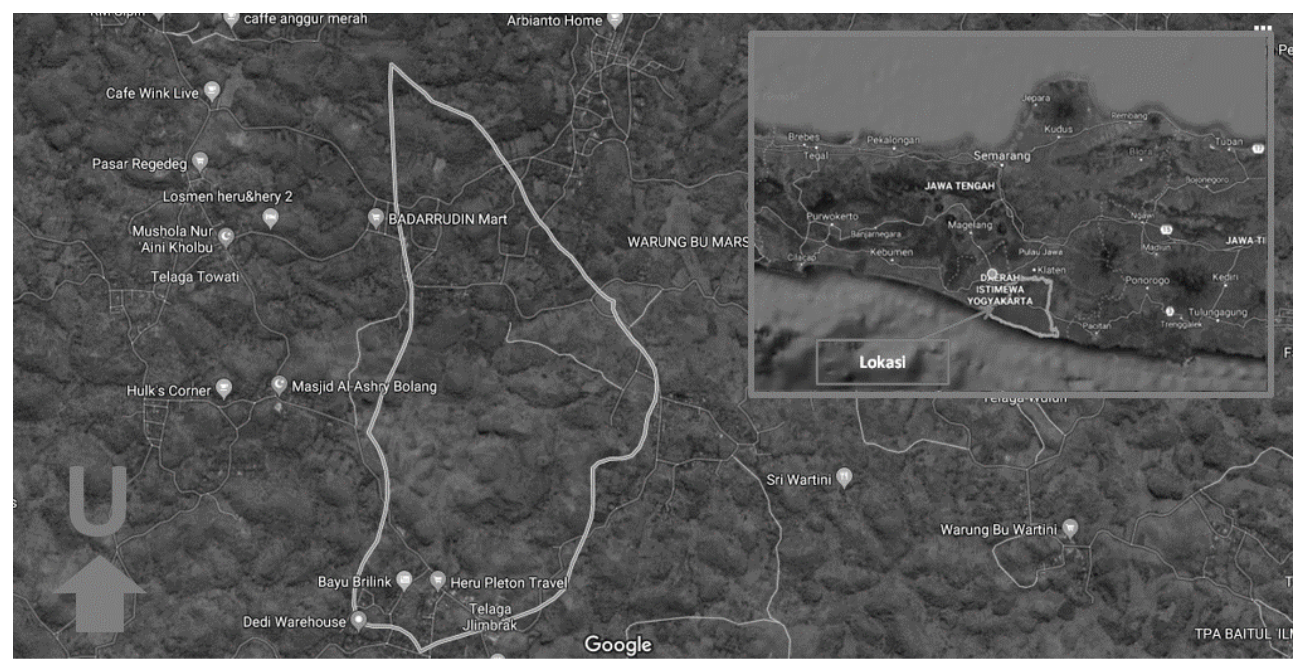

Fig. 2. Location of drinking water treatment systems in Temuireng, Girisuko, Panggang, Gunung Kidul, Yogyakarta.

In Temuireng village, there were approximately 269 families living with more than 1000 person who need clean water. Before the water treatment system existed, people used rainwater with a shelter like Fig. 3. Water quality in the rainy season before people use a drinking water treatment system containing E-coli 9000 per $100 \mathrm{ml}$ and total Coliform bacteria 28000 per $100 \mathrm{ml}$. In the moderate rainy season, total coliform 4000 per 100 and in dry season total Coliform 400 per $100 \mathrm{ml}$ with the maximum regulation 50 per $100 \mathrm{ml}$ (Sugiarto \& Suharwanto, 2017)

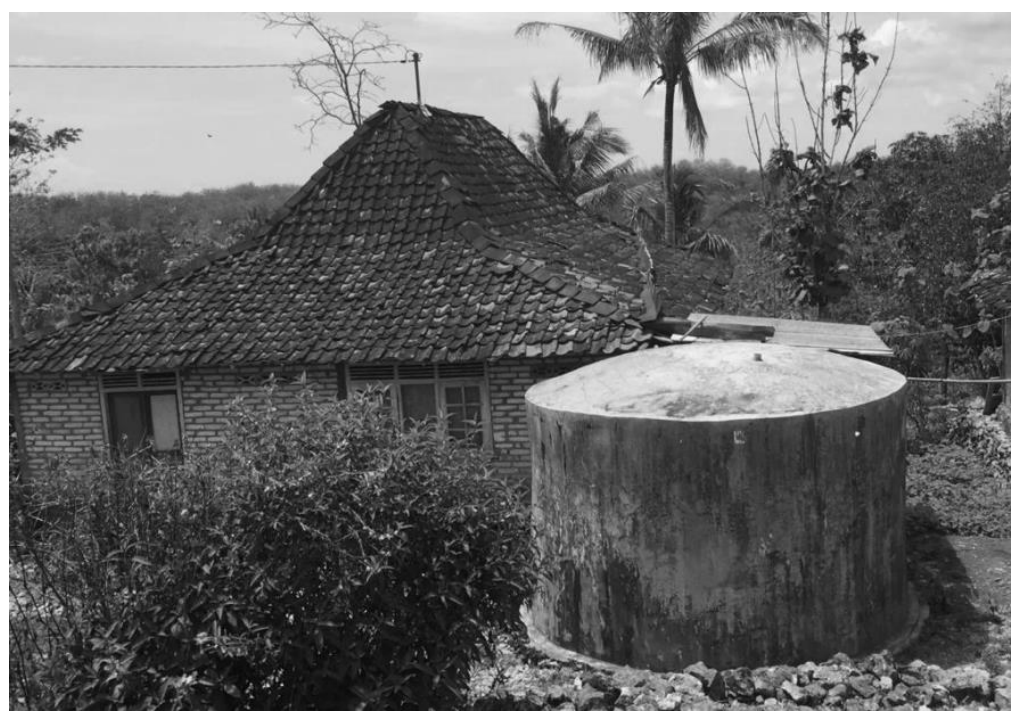

Fig. 3. The shelter of rainwater.

From survey activities and identification of community needs, there are several needs for clean water that can be seen in Tab. 1. 
Table 1.

Needs of People in Temuireng.

\begin{tabular}{|l|l|l|}
\hline \multicolumn{3}{|c|}{ Community needs } \\
\hline Clean water & Automatic water treatment & Enough water \\
\hline Healthy water & Continuous water availability & Cheap and affordable water \\
\hline Easy to get water & $\begin{array}{l}\text { Easy maintenance the tools/ } \\
\text { systems }\end{array}$ & Easy operate the systems \\
\hline
\end{tabular}

\subsection{Product Concept Design}

Product concept design is the most important stage in product development. In this research the product concept design is considering the needs, technology and SHE IS FATER. Fig. 4 explains the product concept design in this research.

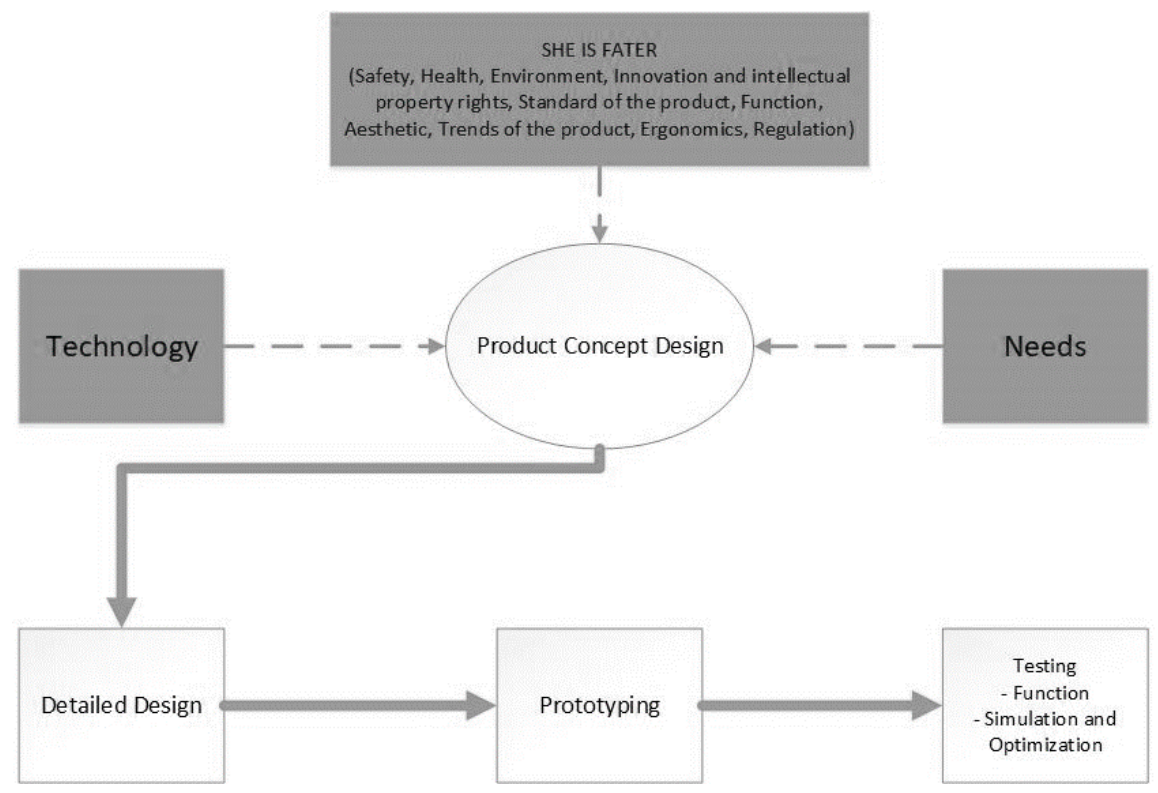

Fig. 4. Product concept design and process in this study.

The needs of people in Temuireng village can be seen in Tab. 1. From the needs that have been obtained, the next step is to design an automatic drinking water treatment system. The needs of these people are then combined with technology (automated systems) and other elements such as SHE IS FATER. Nowadays, automation is a technology that can be applied in almost everything. Automation can help people to manage productivity, improve quality, reduce downtimes, and also reduce operating cost. This technology can apply in water treatment system. The design of the product considering aspect SHE IS FATER besides the two factor technology and needs. After the design concept is reached, the next step is to make a detailed design. 


\subsection{Product Design}

Product design in this research improves the design from Sugiarto et al. (2017). In this automation drinking water treatment system, the automation control will be installed in three areas. The automation will be installed mainly before the tanks because the main function of this automation is to control the volume of the water in each tank. The selenoid will be installed in output of mixer, output of alum and alum tube. Fig. 5 shows the process design concept for this water treatment system.

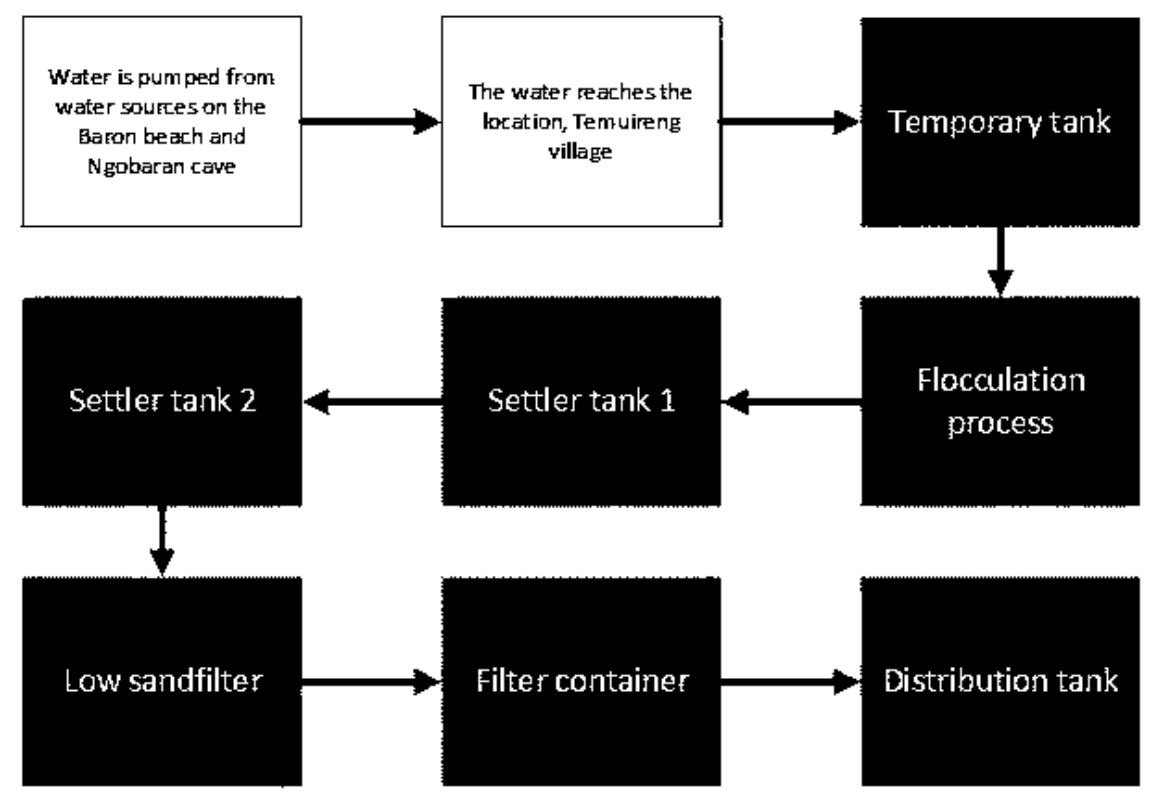

Fig. 5. Process concept design of this water treatment system.

First, water is pumped from the water source in Baron beach area and Ngobaran cave. Then after the water reaches the Temuireng village, Girisuko, Panggang, Gunung Kidul, the water is pumped to reach in temporary tank that located in higher area. The water in the temporary tank then was streamed to flocculation process to reduce the E-coli and total coliform. This process used natural clot like moringa.

In the next process, water that has been processed in flocculation then was streamed to settler tank 1 and settler tank 2. The settler tank was designed twice to optimize the sedimentation process. The result of this sedimentation process then was streamed to low sand filter process. This process used zeolite and charcoal. Then the next process was test the quality of the water in the filter container, if the water still contained high e-coli and coliform then chlorination should be done. If the quality of the water has been achieved then the next process water was streamed to distribution tank and the water ready to be distributed.

\subsection{Prototyping}

Prototyping in this research is made in laboratory scale. After a detailed design has been obtained, the next step is to make a prototype. Before the automation system be applied in real system, it needs a simulation and optimization. One of the way to running the simulation 
and optimization is making a prototype. Prototype in this research will be made in laboratory scale, with the same process, function, and material (water) as a real system.

The equipment used in this prototype is coagulant shelter, mixer shelter, sedimentation shelter, filtration shelter, product shelter, pump, solenoid valve pneumatic, and control panel. After the prototype has been made, the next step is testing the prototype and then evaluate. In the prototype testing step, the prototype function will be checked and then the simulation and optimization will be run. Fig. 6 is the sample of the prototype in a laboratory scale.

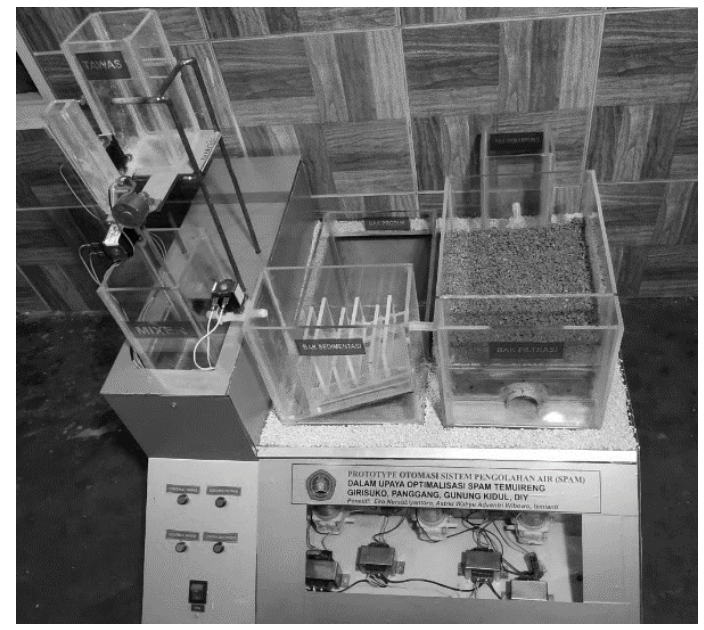

Fig. 6. Prototype in laboratory scale

In this prototype the automation were installed with solenoid. With this solenoid, the water will automatically come out when the engine is started and water will automatically stop when the tank is full. This applies to all tanks so that no manpower is needed to turn on and turn off the water tap.

\subsection{Data Analysis}

From the prototype test results, the TDS of water can be reduced from $400 \mathrm{ppm}$ to below $160 \mathrm{ppm}$. The results of this TDS are in the category of excellent based on WHO (World Health Organization, 1993). Reduction of TDS in each process can be seen in Fig. 7.

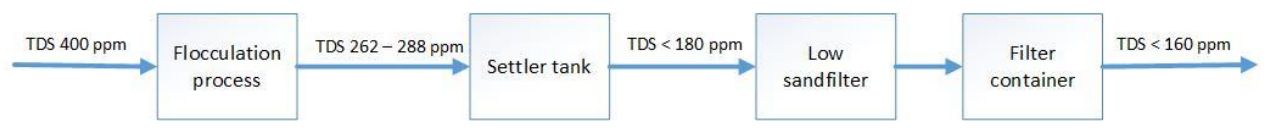

Fig. 7. Reduction of TDS in each process.

Tab. 2 shows the results of laboratory tests of water source (raw material) from PDAM Gunung Kidul Regency and water products from drinking water treatment system in Temuireng. 
Table 2.

Laboratory test from water source and drinking water treatment system.

\begin{tabular}{|c|c|c|c|c|c|}
\hline \multirow{2}{*}{ No. } & \multirow{2}{*}{ Parameter } & \multirow{2}{*}{ unit } & \multirow{2}{*}{$\begin{array}{c}\text { Maximum } \\
\text { content }\end{array}$} & \multicolumn{2}{|c|}{ Result of test } \\
\hline & & & & $I^{*}$ & II $^{* *}$ \\
\hline 1 & $\begin{array}{l}\text { Total Suspended Solid } \\
\text { (TSS) }\end{array}$ & $\mathrm{mg} / \mathrm{l}$ & $(-)$ & 13 & 12 \\
\hline 2 & $\begin{array}{l}\text { Total Dissolve Solid } \\
\text { (TDS) }\end{array}$ & $\mathrm{mg} / \mathrm{l}$ & 500 & 402 & 251,5 \\
\hline 3 & Hardness & $\mathrm{mg} / \mathrm{l}$ & 500 & 178 & 162 \\
\hline 4 & Dissolved Oxygen & $\mathrm{mg} / \mathrm{l}$ & $(-)$ & 7,58 & 7,78 \\
\hline 5 & Turbidity & NTU & 5 & 0,94 & 0,24 \\
\hline 6 & Number of coliform & $\mathrm{JPT} / 100 \mathrm{ml}$ & 0 & None & None \\
\hline
\end{tabular}

Tab. 3 shows the results of laboratory tests for the prototype of an automated drinking water treatment system.

Table 3.

Laboratory tests for the prototype of automated drinking water treatment system.

\begin{tabular}{|c|c|c|c|c|c|c|}
\hline \multirow{2}{*}{ No } & \multirow{2}{*}{ Parameter } & \multirow{2}{*}{ Unit } & \multirow{2}{*}{$\begin{array}{l}\text { Maximum } \\
\text { content }\end{array}$} & \multicolumn{3}{|c|}{ Result of test } \\
\hline & & & & $\mathrm{I}$ & II & III \\
\hline 1 & $\begin{array}{l}\text { Total Suspended Solid } \\
\text { (TSS) }\end{array}$ & $\mathrm{mg} / \mathrm{l}$ & $(-)$ & 10 & 7 & 9 \\
\hline 2 & $\begin{array}{l}\text { Total Dissolve Solid } \\
\text { (TDS) }\end{array}$ & $\mathrm{mg} / \mathrm{l}$ & 500 & 159 & 160,5 & 162 \\
\hline 3 & Hardness & $\mathrm{mg} / \mathrm{l}$ & 500 & 78 & 54 & 60 \\
\hline 4 & Dissolved Oxygen & $\mathrm{mg} / \mathrm{l}$ & $(-)$ & 7,58 & 7,19 & 7,78 \\
\hline 5 & Turbidity & NTU & 5 & 0,39 & 0,42 & 0,27 \\
\hline 6 & Number of coliform & $\mathrm{JPT} / 100 \mathrm{ml}$ & 0 & Nihil & Nihil & Nihil \\
\hline
\end{tabular}

I, II, III: test content from prototype of automated drinking water treatment systems in Temuireng.

According to Permenkes 492 / Menkes / Per / IV / 2010 the maximum allowable level for TSS is zero. The processed product from the Temuireng drinking water treatment system is $12 \mathrm{mg} / 1$ which means it still does not meet the required standards. Based on Table 3 laboratory test results for TSS parameters in the water product automation drinking water treatment system that is replicated 3 times is $10 \mathrm{mg} / 1,7 \mathrm{mg} / 1$ and $9 \mathrm{mg} / 1$ shows there is an increase in the quality standard of drinking water, although it still does not meet drinking water quality standards in accordance with the Regulation of the Minister of Health.

Hardness is the nature of water caused by the presence of valence metal ions, for example $\mathrm{Mg} 2+, \mathrm{Ca} 2+, \mathrm{Fe}+$ and $\mathrm{Mn}+$. Total hardness is hardness caused by the presence of $\mathrm{Ca} 2+$ and $\mathrm{Mg} 2+$ ions together. The results of the measurement of hardness levels (table 2) for source water is $178 \mathrm{mg} / 1$ and hardness levels after processing with drinking water treatment system is $162 \mathrm{mg} / \mathrm{l}$. According to Permenkes 492 / Menkes / Per / IV / 2010 these results are still below the required threshold, so it is suitable as drinking water. Table 2 shows 
the results of the water test for drinking water treatment system automation products, the hardness content is quite low when compared to the results of the SPAM treated water test. The hardness content of processed automated drinking water treatment system products is 78 $\mathrm{mg} / 1,54 \mathrm{mg} / 1$ and $60 \mathrm{mg} / 1$ which qualify as a source of drinking water and clean water.

\section{CONCLUSIONS}

The existing drinking water treatment system in Temuireng village, Girisuko, Panggang, Gunung Kidul need an improve design to optimize the function of the water treatment. Automation is one of the main needs of the water treatment system. From this research, the new design of automation drinking water treatment system has been obtained. The design considering the need of people, technology, and SHE IS FATER (1) SHE (Safety, Health, Environment), (2) Innovation and intellectual property rights, (3) Standard of the product, (4) Function, (5) Aesthetics, (6) Trends of the product, (7) Ergonomics, (8) Regulation. With the new design of the drinking water treatment system, the operating cost will be reduced and the quality of the water be improved. From the results of laboratory tests, the quality of source water and treated water in the drinking water treatment system increases in quality.

\section{ACKNOWLEDGMENT}

The authors acknowledge the support of Lembaga Penelitian dan Pengabdian Masyarakat (LPPM) Universitas Pembangunan Nasional Veteran Yogyakarta.

\section{R E F E R E N C E S}

Abu Hasan, H., Muhammad, M. H., \& Ismail, N. I. (2020). A review of biological drinking water treatment technologies for contaminants removal from polluted water resources. Journal of Water Process Engineering, 33(May 2019), 101035. https://doi.org/10.1016/j.jwpe.2019.101035

Apip, Sagala, S. A., \& Pingping, L. (2015). Overview of Jakarta Water- Related Environmental Challenges. Water and Urban Initiative Working Paper Series, 4(April 2015), 1-5.

Chamchati, H., \& Bahir, M. (2011). Contribution of climate change on water resources in semi-aride areas; example of the Essaouita Basin (Morocco). Geographia Technica, 1, 1-8

Dubey, S., Agarwal, M., Gupta, A. B., Dohare, R. K., \& Upadhyaya, S. (2016). Automation and control of water treatment plant for defluoridation. International Journal of Advanced Technology and Engineering Exploration, 4(26), 6-11. https://doi.org/10.19101/ijatee.2017.426002

Dwianika, A., Murwaningsari, E., \& Suparta, W. (2020). Analysis of water awareness, accountability, and governance to improve sustainability of firm's performance in urban areas. Geographia technica,15(1), 33-42. https://doi.org/10.21163/GT

Gowtham, R., Varunkumar, M. C., \& Tulsiram, M. P. (2017). Automation in Urban Drinking Water Filtration, Water Supply Control, Water Theft Identification Using PLC and SCADA and Self Power Generation in Supply Control System. International Journal of Advanced Research in Electronics and Communication Engineering, 3(7), 698-703.

Handayani, W. S., Kusnayat, A., Sukma, D., \& Atmaja, E. (2017). Design of Automation System for Water Treatment and. 4(2), 3020-3028.

Haryadi, A., \& Sudarmadji. (2014). Kajian Potensi Mata Air di Kawasan Karst Gunung Kidul Study of Potential Springs in the Gunung Kidul Karst Area. Jurnal Bumi Indonesia, 3(3), 1-10.

Hasan, H. A., Abdullah, S. R. S. A., Kofli, N. T., \& Yeoh, S. J. (2016). Interaction of environmental factors on simultaneous biosorption of lead and manganese ions by locally isolated Bacillus cereus. Journal of Industrial and Engineering Chemistry, 37, 295-305. 
Kabisch, S. (2016). Integrated Surveying for the Archaeological. Geographia Technica, 11(2), 39-50. https://doi.org/10.21163/GT

Kardono. (2007). Condition of Water Resource in Indonesia and. Environmental Technology, 3(2). Retrieved from https://media.neliti.com/media/publications/245430-condition-of-waterresource-in-indonesia-e8afa79f.pdf

Luo, P., Kang, S., Apip, Zhou, M., Lyu, J., Aisyah, S., ... Nover, D. (2019). Water quality trend assessment in Jakarta: A rapidly growing Asian megacity. PLoS ONE, 14(7), 1-17. https://doi.org/10.1371/journal.pone.0219009

Nandiyanto, A. B. D., \& Haristiani, N. (2016). Design of SImple Water Treatment System for Cleaning Dirty Water in the Rural Area. Journal of Physics: Conference Series, 755(1). https://doi.org/10.1088/1742-6596/755/1/011001

Nistor, M., Man, T. C., Benzaghta, M. A., Vasu, N. N., Dezsi, Ş., \& Kizza, R. (2018). Land cover and temperature implications for the seasonal evapotranspiration in europe. Geographia Technica, 13(1), 85-108. https://doi.org/10.21163/GT

Rotjanakusol, T., \& Laosuwan, T. (2019). An investigation of drought around chi watershed during ten-year period using terra/modis data. Geographia Technica, 14 (2), 74-83. https://doi.org/10.21163/GT

Sugiarto, B., \& Suharwanto. (2017). Pengembangan Pemanfaatan Pengolahan Air Dalam Upaya Pemenuhan Kebutuhan Air di Dusun Temuireng , Desa Girisuko , Panggang , Gunungkidul Developing the Utilization of Water Treatment Technology to Fill Water Demand at Temuireng-Girisuko Village. Eksergi, 14(2), 40-52.

Tontowi, A. E. (2016). Desain Produk Inovatif dan Inkubasi Bisnis Kompetitif Innovative Product Design and Competitive Business Incubation. Gadjah Mada University Press.

Wiyono, N., Faturrahman, A., \& Syauqiah, I. (2017). Sistem Pengolahan Air Minum Sederhana (Portable Water Treatment). Konversi, 6(1), 27. https://doi.org/10.20527/k.v6i1.3012

World Health Organization. (1993). Guidelines for drinking-water quality. World Health Organization.

Yang, Y., Liu, Y., Phang, C. W., \& Wei, J. (2020). Using microblog to enhance public service climate in the rural areas. Government Information Quarterly, 37(1), 101402.

https://doi.org/10.1016/j.giq.2019.101402 